\title{
Diuretic Effects of L-Threo-3,4-Dihydroxyphenylserine (L-Threo-DOPS) in Anesthetized Rats
}

\author{
Shiro MORIMOTO, Yasuo MATSUMURA, Tadashi OHYAMA, \\ Hiroshi SHINYAMA, Toshio ICHIHARA, Yoshiyuki TAKAHASHI \\ and Kazuhiro HISAKI \\ Department of Pharmacology, Osaka University of Pharmaceutical Sciences, \\ 2-10-65 Kawai. Matsubara, Osaka 580. Japan
}

Acrepted November 24, 1989

\begin{abstract}
A synthetic amino acid. L-threo-3.4-dihydroxyphenylserine ( $L$-threoDOPS), can be converted to (-)-norepinephrine (NE) by aromatic $L$-amino acid decarboxy!ase (AADC) in various mammalian tissues. Recent studies have indicated the pressor and diuretic effects of L-threo-DOPS. In this study, we examined the effects of $L$-threo-DOPS on renal hemodynamics and function in anesthetized rats, and evaluated possible mechanisms of the diuresis. Intravenous infusion of L-threo-DOPS at $120 \mu \mathrm{g} / \mathrm{kg} / \mathrm{min}$ exerted a significant increase in mean arterial pressure (MAP). There was a slight but nonsignificant decrease in renal blood flow (RBF). Although the glomerular filtration rate (GFR) remained at a constant level, urine flow (UF) and urinary sodium excretion $\left(U_{\mathrm{Na}} V\right)$ increased significantly during the drug infusion. Pretreatment with AADC inhibitor, benserazide. completely blocked both the pressor and diuretic effects of L-threo-DOPS. When the renal perfusion pressure was protected from the pressor effect of the drug by using a Blalock clamp, the drug-induced diuresis was abolished. The diuretic effect of L-threo-DOPS was markedly attenuated by the administration of phentolamine. There was a positive correlation between plasma NE concentration and UF during the infusion of L-threo-DOPS. Intrarenal arterial infusion of L-threoDOPS at $20 \mu \mathrm{g} / \mathrm{kg} / \mathrm{min}$ was without effect on renal function. These results indicate that diuresis and natriuresis induced by L-threo-DOPS are dependent on the pressor effect of NE via peripheral $\alpha$-adrenoceptor activation.
\end{abstract}

L-Threo-3,4-dihydroxyphenylserine threo-DOPS) is a synthetic amino acid and can be decarboxylated by aromatic L-amino acid decarboxylase (AADC) to form (-)norepinephrine (NE) in vitro (1) and in vivo (2). L-Threo-DOPS has been reported to have beneficial effects on akinesia or freezing phenomenon in parkinsonian patients (3) and on orthostatic hypotension in familial amiloid polyneuropathy (4). The hypothermia (5) and ptosis (6) in mice induced by reserpine. an agent which causes both central and peripheral depletion of NE (7), can be reversed by $L$-threo-DOPS in a dose-dependent manner. Furthermore, L-threo-DDPS produces a slow-onset and long-lasting hypertensive effect in anesthetized rats (8). Thus, this synthetic amino acid appears to be useful as a central and peripheral precursor of NE for various disorders in which noradrenergic transmission is deficient.

Recently, Katsube et al. (9) demonstrated that L-threo-DOPS administered orally in rats and mice produced a dose-dependent diuretic action. They suggested that the diuretic action was mainly due to NE formed by the decarboxylation, based on the findings that the treatment with AADC inhibitors effectively blocked the diuresis. In this study. we examined the effects of L-threo-DOPS on renal hemodynamics and function in anesthetized rats, and we evaluated possible mechanisms of the drug-induced diuresis. 


\section{Materials and Methods \\ Animal preparation}

Male Sprague-Dawley rats weighing 300$330 \mathrm{~g}$ were anesthetized with sodium pentobarbital $(40 \mathrm{mg} / \mathrm{kg}$, i.p.) and placed on a heated surgical tray that maintained rectal temperature between $37^{\circ} \mathrm{C}$ and $38^{\circ} \mathrm{C}$. Supplemental doses of sodium pentobarbital were intravenously infused $(30 \mathrm{mg} / \mathrm{kg} / \mathrm{hr})$ to maintain a stable state of anesthesia. After tracheotomy, the right femoral vein was cannulated for infusion of physiological saline containing $1.5 \%$ inulin. The left carotid artery was also cannulated for blood sampling and for blood pressure measurements. Mean arterial pressure (MAP) was monitored continuously with a pressure transducer (Nihon Kohden AP601G). After an abdominal midline incision was made, the left kidney was exposed, and the renal artery was carefully stripped of connective tissues, followed by the application of $5 \%$ phenol in $70 \%$ ethanol to exclude the influence of sympathetic nerve activity. In some experiments, a curved 30 gauge needle connected to polyethylene tubing was inserted into the renal artery for intrarenal drug infusion. An electromagnetic flow probe $(1.0 \mathrm{~mm}$ in diameter) connected to a square-wave flowmeter (Nihon Kohden MFV-2100) was positioned on the renal artery for continuous measurements of renal blood flow (RBF). A polyethylene cannula was inserted into the left ureter for urine collection. The urinary bladder was cannulated to ensure free drainage of urine from the right kidney. At the end of the surgical operation. about $3 \mathrm{ml}$ of physiological saline containing $1.5 \%$ inulin was infused slowly to supplement the loss of body fluid and as a priming dose of inulin: this was followed by a sustained infusion of the same solution at a rate of 0.04 $\mathrm{ml} / \mathrm{min}$. MAP and RBF were continuously recorded on a polygraph (Nihon Kohden RM 6000). About $1 \mathrm{hr}$ was allowed for stabilization of MAP. RBF and urine flow (UF).

\section{Experimental protocol}

Series 1: The experiment consisted of six 20 -min clearance periods. After the first control urine collection. L-threo-DOPS $(40 \mu \mathrm{g} /$ $\mathrm{kg} / \mathrm{min}$ or $120 \mu \mathrm{g} / \mathrm{kg} / \mathrm{min})$ or vehicle $(0.9 \%$ saline) was infused into the right femoral vein.
Ten minutes after the start of the infusion, urine collection was performed during 3 consecutive 20 -min periods. Ten minutes after termination of the infusion, another two consecutive 20-min samples were collected as samples of the recovery period. Blood samples $(0.2 \mathrm{ml}$ each) were obtained from the left carotid artery at the end of the control. first and third experimental periods, and at the end of the first recovery period. The blood loss was supplemented by ar equal volume of $0.9 \%$ saline. Plasma was immediately separated by centrifugation.

Series 2: This series of experiments was performed to examine the effects of AADC inhibition on L-threo-DOPS-induced renal actions. Animals were treated with an $A A D C$ inhibitor benserazide (50 mg/ $\mathrm{kg}$, i.p.) $1 \mathrm{hr}$ prior to the start of the infusion of L-threoDOPS $(120 \mu \mathrm{g} / \mathrm{kg} / \mathrm{min})$.

Series 3: In this series of experiments, the relationship between $L$-threo-DOPS-induced pressor effects and the renal actions was investigated. During the drug infusion, the left renal perfusion pressure was maintained at a preinfusion level by aortic constriction with a Blalock clamp attached at the aorta just above the origin of the left renal artery. MAP below the clamp was recorded from a catheter inserted into the right femoral artery and advanced into the aorta, and was used as an index of the left renal perfusion pressure. MAP above the clamp was recorded from a catheter inserted into the left carotid artery.

Series $4:$ in this series of experiments, the effects of the $\alpha$-adrenoceptor antagonist phentolamine on L-threo-DOPS-induced renal actions were examined. Animals were treated with phentolamine $(\hat{\imath} \mathrm{mg} / \mathrm{kg}$, i.v., followed by a continuious infusion of $0.6 \mathrm{mg} /$ $\mathrm{kg} / \mathrm{hr}$ ) $1 \mathrm{hr}$ prior to the start of the infusion of L-threo-DOPS $(120 \mu \mathrm{g} / \mathrm{kg} / \mathrm{min})$. $\alpha$-Adrenergic blockade was verified by the abolishment of the pressor effect of NE $(0.5 \mu \mathrm{g} / \mathrm{kg}, i . v$. $)$.

Series 5: This series of experiments was performed to examine the direct action of $L$ threo-DOPS on renal function. A nonhypertensive dose of L-threo-DOPS $(20 \mu \mathrm{gg} / \mathrm{kg} /$ min) was administered directly into the left renal artery.

In Series 2-5, the technique for urine collection and blood sampling was the same as 
described for the Series 1 experiments.

Series 6: In this series of experiments, Lthreo-DOPS and NE concentrations in the plasma were determined after administration of L-threo-DOPS. One hour after the start of the infusion of vehicle or L-threo-DOPS. $3 \mathrm{ml}$ of arterial blood was collected, and plasma was immediately separated.

\section{Analytical procedures}

Urine and plasma inulin levels were measured by spectrofluorometry (Hitachi 650-60) according to the method of Vurek and Pegram (10). The glomerular filtration rate (GFR) was calculated from the inulin clearance. Sodium and potassium were determined using a flame photometer (Hitachi 205D).

L-Threo-DOPS and NE concentrations in plasma were measured by high performance liquid chromatography (HPL.C) with an amperometric detector after extraction by the method of Suzuki et al. (11). Briefly, $1 \mathrm{ml}$ of plasma was mixed with $5 \mu \mathrm{g}$ of DL- $\alpha$-methyldihydroxyphenylalanine ( $\alpha$-methyl-DOPA, an internal standard for L-threo-DOPS), $5 \mathrm{ng}$ of 3,4-dihydroxybenzylamine (DHBA, an internal standard for $N E$ ) and $1 \mathrm{ml}$ of $1 \mathrm{M}$ ammonium phosphate buffer $(\mathrm{pH} \mathrm{7.5)}$, and applied to a column of boric acid gel $(0.5 \times 5$ $\mathrm{cm})$. L-Threo-DOPS and $\alpha$-methyl-DOPA were eluted with $4 \mathrm{ml}$ of $10 \%$ sorbitol solution from the gel, and NE and DHBA were eluted with $2 \mathrm{ml}$ of $1.3 \mathrm{M}$ acetic acid in methanol after washing with $60 \mathrm{ml}$ of distilled water and $2 \mathrm{ml}$ of $0.1 \mathrm{~N}$ acetic acid in methanol. The eluate was dried by a stream of $\mathrm{N}_{2}$ gas, and the residue was dissolved in distilled water. Subsequently, an aliquot of the eluate was injected into an HPLC (Yanaco L-5000) equipped with an amperometric detector (Yanaco VMD-101) and a Yanapac ODS-A column.

\section{Drugs}

L-Threo-DOPS and benserazide were kindly supplied by Sumitomo Pharmaceuticals Co., Ltd. (Osaka, Japan). Phentolamine hydrochloride was a kind gift from CibaGeigy, Ltd. (Takarazuka, Japan). All other chemicals used were of analytical grade.

\section{Statistical analysis}

All values were expressed as the meant S.E. For statistical analysis, we used the Kruskal-Wallis nonparametric analysis of variance followed by a Dunnett-type or a Scheffe-type multiple range test for multiple comparisons. In all comparisons, differences were considered significant at $P<0.05$.

\section{Results}

Renal effects of intravenous infusion of L-threo-DOPS: Intravenous infusion of the vehicle (the time control experiments) had no significant effect on renal hemodynamics and function, although MAP tended to decrease time-dependently during the experiments (from $116 \pm 3$ in the control period to $107 \pm 5$ $\mathrm{mmHg}$ in the second recovery period). Administration of L-threo-DOPS at $40 \mu \mathrm{g} / \mathrm{kg} /$ min produced a slight increase in MAP, but the changes were not statistically significant compared with the time control experiments. There were no alterations in renal parameters except for slight increases in UF and urinary excretion of sodium $\left(\mathrm{U}_{\mathrm{Na}} \mathrm{V}\right)$. When L-threoDOPS was administered at $120 \mu \mathrm{g} / \mathrm{kg} / \mathrm{min}$, MAP increased significantly from a control value of $117 \pm 2$ to $137 \pm 4 \mathrm{mmHg}$ at $1 \mathrm{hr}$ after the drug infusion. Although slight and nonsignificant decreases in RBF were observed. there was no change in GFR throughout the experiments. L-Threo-DOPS at this dose produced significant diuretic and natriuretic effects. In the third experimental period. UF and $U_{\mathrm{Na}} V$ increased to about 2- and 2.5-fold of each control value, respectively. These effects were recovered gradually after termination of the drug infusion. Urinary excretion of potassium $\left(U_{k} V\right)$ did not change throlighout the experiments (Fig. 1).

The effects of AADC inhibition on the Lthreo-DOPS $(120 \mu \mathrm{g} / \mathrm{kg} / \mathrm{min})$-induced hypertensive and diuretic actions are depicted in Table 1. Treatment with the AADC inhibitor benserazide abolished the increases in MAP, UF and $U_{\mathrm{Na}} V$ induced by the infusion of L-threo-DOPS.

Figure 2 shows the effects of L-threoDOPS $(120 \mu \mathrm{g} / \mathrm{kg} / \mathrm{min})$ on renal hemodynamics and functions during aortic constriction. MAP above the clamp increased to a similar extent to that in the group without the clamp. MAP below the clamp maintained a constant level throughout the experiments. RBF decreased by approximately $20 \%$ during the drug infusion, but the changes were not 


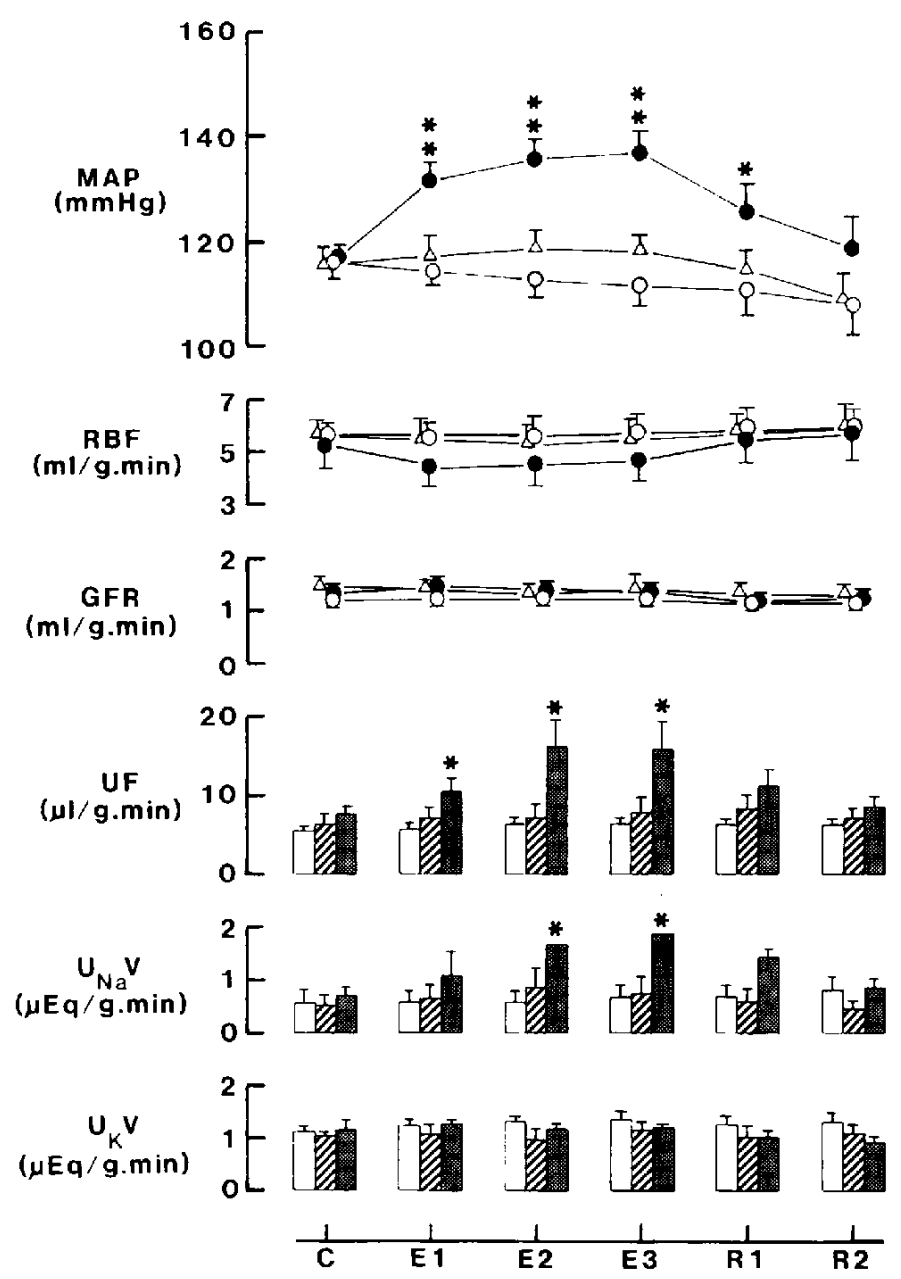

Fig. 1. Renal hemodynamic and excretory responses to intravenous infusion of L-threo-DOPS. Values are means $\pm S . E . \quad{ }^{*} P<0.05,{ }^{*} P<0.01$, compared with the value observed in the time control in the same period. $\bigcirc$. $\square$. Time control $(n=9) ; \triangle$. WIII). L-Threo-DOPS $(40 \mu \mathrm{g} / \mathrm{kg} / \mathrm{min})(n=6) ; 0$. B. LThreo-DOPS $(120 \mu \mathrm{g} / \mathrm{kg} / \mathrm{min})(\mathrm{n}=9)$.

statistically significant. There was no change in GFR throughout the experiments. Although UF, $\mathrm{U}_{\mathrm{Na}} V$ and $\mathrm{U}_{\mathrm{K}} \mathrm{V}$ decreased by about $25 \%$. $35 \%$ and $40 \%$ during the drug infusion, respectively, these changes were also statistically nonsignificant.

The effects of $\alpha$-adrenergic blockade on the $\mathrm{L}$-threo-DOPS $(120 \mu \mathrm{g} / \mathrm{kg} / \mathrm{min})$-induced hypertensive and diuretic actions are shown in Fig. 3. The $\alpha$-adrenoceptor antagonist phentolamine attenuated the hypertensive effect induced by L-threo-DOPS, but during L-threo-DOPS infusion MAP remained at a somewhat high level (about $10 \mathrm{mmHg}$ above the control value). Simultaneously, the diuretic effect induced by L-threo-DOPS was markedly attenuated by $\alpha$-adrenergic blockade, although a slight and nonsignificant increase in UF (about 30\%) was observed in the third experimental period. There were no significant changes in $U_{\mathrm{Na}} V$ and $U_{k} V$.

Renal effects of intrarenal arterial infusion of L-threo-DOPS: In order to examine the direct effect of $L$-threo-DOPS on renal function, an intrarenal arterial infusion of $L$-threoDOPS was performed. As shown in Fig. 4. no significant alterations were observed in all the variables. In some rats, L-threo-DOPS 


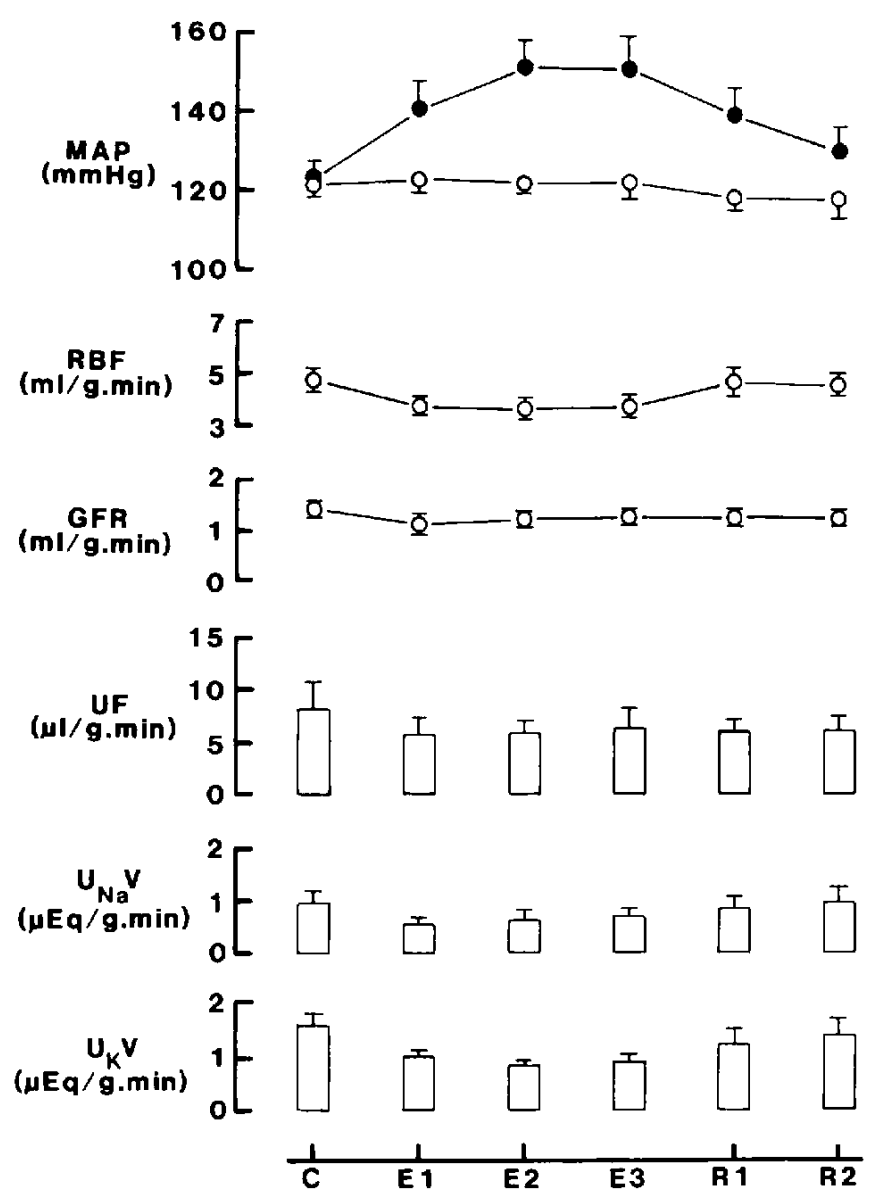

Fig. 2. Effects of aortic clamping on renal hemodynamic and excretory responses to intravenous infusion of L-threo-DOPS $(120, \mu \mathrm{g} / \mathrm{kg} / \mathrm{min})$. MAP below the clamp (O) was recorded from a catheter inserted into the right femoral artery, and it was used as an index of the left renal perfusion pressure. MAP above the clamp (O) was recorded from a catheter inserted into the left carotid artery. Values are means $\pm S . E$. $(n=8)$.

was infused after pretreatment with benserazide, since AADC is abundant in the kidney tissue (12). L-Threo-DOPS after AADC inhibition was also without effect on renal function (data not shown).

L-Threo-DOPS and NE concentrations in plasma after administration of L-threo-DOPS: Plasma NE concentration in control rats was $0.74 \pm 0.12 \mathrm{ng} / \mathrm{ml}$. When L-threo-DOPS was administered intravenously, dose-related increases in plasma NE concentration were observed. When the higher dose, was administered, the NE concentration increased to about 7 -fold the control value. However. this increasing effect was significantly attenuated by pretreatment with the $A A D C$ inhibitor benserazide. Plasma L-threo-DOPS concentrations were also elevated following the administration of this drug. Pretreatment with benserazide produced a further increase in the concentration of L-threo-DOPS (Fig. 5).

\section{Discussion}

In the present study, the intravenous infusion of L-threo-DOPS at a higher dose $(120 \mu \mathrm{g} / \mathrm{kg} / \mathrm{min})$ produced a pressor effect and a diuretic effect in anesthetized rats. These effects were sustained during the infusion and recovered gradually after cessation of the infusion. To evaluate the possible 
Table 1. Renal hemodynamic and excretory responses to intravenous infusion of L-threo-DOPS (120 $\mu \mathrm{g} / \mathrm{kg} / \mathrm{min}$ ) before $(-\mathrm{B})$ and after $(+\mathrm{B})$ benserazide treatment

\begin{tabular}{|c|c|c|c|c|c|c|c|c|c|c|}
\hline & \multicolumn{2}{|c|}{$\begin{array}{c}\mathrm{MAP} \\
(\mathrm{mmHg})\end{array}$} & \multicolumn{2}{|c|}{$\begin{array}{c}\mathrm{GFR} \\
(\mathrm{ml} / \mathrm{g} \cdot \mathrm{min})\end{array}$} & \multicolumn{2}{|c|}{$\underset{(\mu ! / g \cdot \min )}{\operatorname{UF}}$} & \multicolumn{2}{|c|}{$\begin{array}{c}U_{\mathrm{NaV}} \\
(\mu \mathrm{Eq} / \mathrm{g} \cdot \mathrm{min})\end{array}$} & \multicolumn{2}{|c|}{$\begin{array}{c}U_{\mathbf{K}} V \\
\left(a^{\prime} \sqsubset \mathrm{g} / \mathrm{g} \cdot \mathrm{min}\right)\end{array}$} \\
\hline & $-B$ & $+B$ & $-B$ & $+B$ & $-B$ & $+B$ & $-B$ & $+B$ & $-B$ & $+B$ \\
\hline C & $\begin{array}{l}117 \\
\pm 2\end{array}$ & $\begin{array}{l}123 \\
\pm 7\end{array}$ & $\begin{array}{r}1.38 \\
\pm 0.09\end{array}$ & $\begin{array}{r}1.04 \\
\pm 0.07\end{array}$ & $\begin{array}{r}7.53 \\
\pm 0.78\end{array}$ & $\begin{array}{r}7.43 \\
\pm 1.07\end{array}$ & $\begin{array}{r}0.69 \\
+0.17\end{array}$ & $\begin{array}{r}0.73 \\
\pm 0.13\end{array}$ & $\begin{array}{r}1.15 \\
\pm 0.18\end{array}$ & $\begin{array}{r}1.42 \\
\pm 0.03\end{array}$ \\
\hline E1 & $\begin{array}{l}131 \\
\pm 3\end{array}$ & $\begin{array}{l}116 \\
\pm 6\end{array}$ & $\begin{array}{r}1.47 \\
\pm 0.06\end{array}$ & $\begin{array}{r}0.97 \\
\pm 0.06\end{array}$ & $\begin{array}{l}10.50 \\
\pm 1.61\end{array}$ & $\begin{array}{r}6.42 \\
\pm 0.99\end{array}$ & $\begin{array}{r}1.07 \\
\pm 0.39\end{array}$ & $\begin{array}{r}0.68 \\
\pm 0.17\end{array}$ & $\begin{array}{r}1.24 \\
\pm 0.09\end{array}$ & $\begin{array}{r}1.43 \\
\pm 0.26\end{array}$ \\
\hline E2 & $\begin{array}{l}135^{*} \\
\pm 4\end{array}$ & $\begin{array}{l}106 \\
\pm 7\end{array}$ & $\begin{array}{r}1.36 \\
\pm 0.05\end{array}$ & $\begin{array}{r}1.24 \\
+0.10\end{array}$ & $\begin{array}{l}16.18^{*} \\
\pm 3.47\end{array}$ & $\begin{array}{r}6.80 \\
\pm 1.38\end{array}$ & $\begin{array}{l}1.66^{*} \\
\pm 0.40\end{array}$ & $\begin{array}{r}0.66 \\
\pm 0.26\end{array}$ & $\begin{array}{r}1.18 \\
\pm 0.09\end{array}$ & $\begin{array}{r}1.39 \\
\pm 0.29\end{array}$ \\
\hline E3 & $\begin{array}{l}137^{*} \\
\pm 4\end{array}$ & $\begin{array}{l}104 \\
\pm 6\end{array}$ & $\begin{array}{r}1.37 \\
\pm 0.09\end{array}$ & $\begin{array}{r}1.14 \\
\pm 0.04\end{array}$ & $\begin{array}{l}15.97^{*} \\
\pm 3.50\end{array}$ & $\begin{array}{r}8.00 \\
+1.79\end{array}$ & $\begin{array}{l}1.88^{*} \\
\pm 0.44\end{array}$ & $\begin{array}{r}0.78 \\
\pm 0.39\end{array}$ & $\begin{array}{r}1.20 \\
\pm 0.02\end{array}$ & $\begin{array}{r}1.36 \\
+0.25\end{array}$ \\
\hline $\mathrm{R} 1$ & $\begin{array}{l}125 \\
\pm 5\end{array}$ & $\begin{array}{l}102 \\
\pm 5\end{array}$ & $\begin{array}{r}1.18 \\
\pm 0.11\end{array}$ & $\begin{array}{r}1.04 \\
\pm 0.02\end{array}$ & $\begin{array}{l}11.21 \\
\pm 2.21\end{array}$ & $\begin{array}{r}8.25 \\
\pm 1.88\end{array}$ & $\begin{array}{r}1.41 \\
\pm 0.24\end{array}$ & $\begin{array}{r}0.82 \\
\pm 0.46\end{array}$ & $\begin{array}{r}1.02 \\
\pm 0.13\end{array}$ & $\begin{array}{r}1.36 \\
\pm 0.24\end{array}$ \\
\hline $\mathrm{R} 2$ & $\begin{array}{l}118 \\
\pm 6\end{array}$ & $\begin{array}{l}101 \\
\pm 5\end{array}$ & $\begin{array}{r}1.24 \\
\pm 0.07\end{array}$ & $\begin{array}{r}1.03 \\
\pm 0.01\end{array}$ & $\begin{array}{r}8.60 \\
\pm 1.40\end{array}$ & $\begin{array}{r}7.15 \\
\pm 1.45\end{array}$ & $\begin{array}{r}0.85 \\
\pm 0.19\end{array}$ & $\begin{array}{r}0.76 \\
\pm 0.43\end{array}$ & $\begin{array}{r}0.81 \\
\pm 0.12\end{array}$ & $\begin{array}{r}1.28 \\
\pm 0.20\end{array}$ \\
\hline
\end{tabular}

Values are means \pm S.E. $(n=9) * P<0.05$, compared with the values observed in the control period.

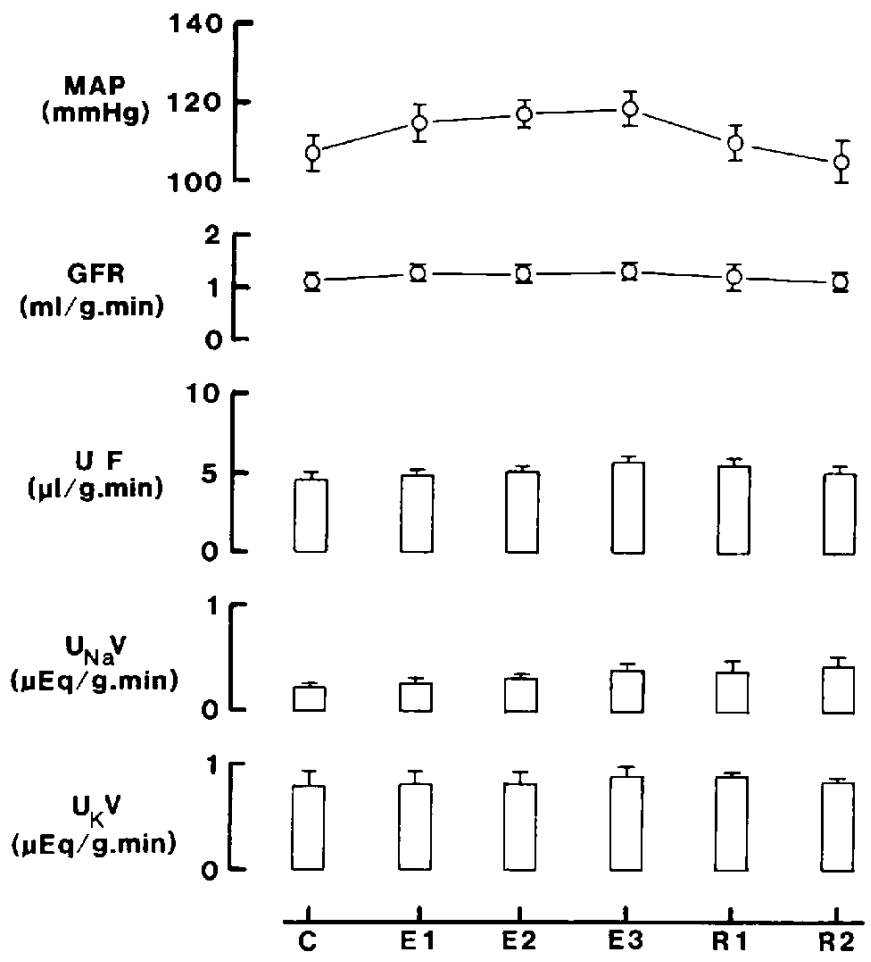

Fig. 3. Effects of pretreatment with phentolamine on renal hemodynamic and excretory responses to intravenous infusion of L-threo-DOPS $(120 \mu \mathrm{g} / \mathrm{kg} / \mathrm{min})$. Values are means $\pm S . E .(n=7)$.

relationships between the hypertension and the diuresis, the effect of L-threo-DOPS on renal function was also examined under the condition where the rats were protected from the drug-induced pressor action with the aortic clamp. When MAP below the clamp 

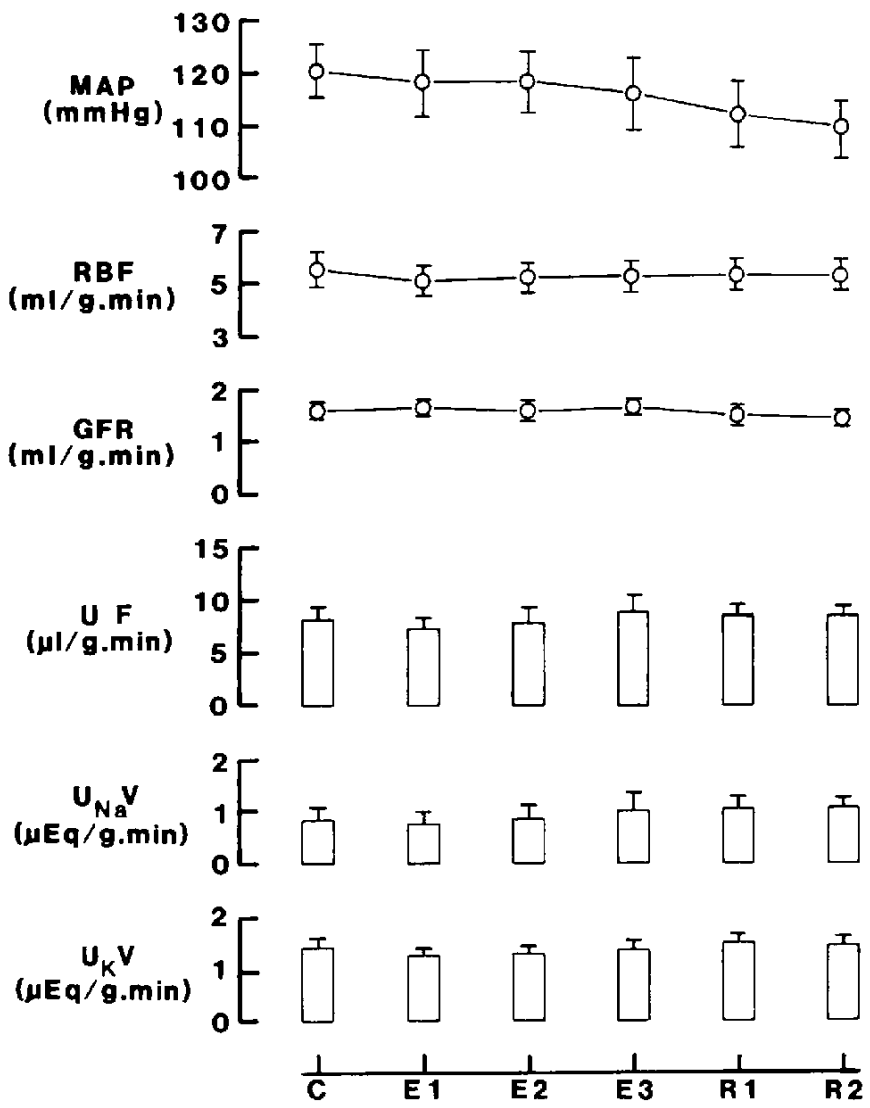

Fig. 4. Renal hemodynamic and excretory responses to intrarenal arterial infusion of L-threo-DOPS (20 $\mu \mathrm{g} / \mathrm{kg} / \mathrm{min})$. Values are means \pm S.E. $(n=8)$.

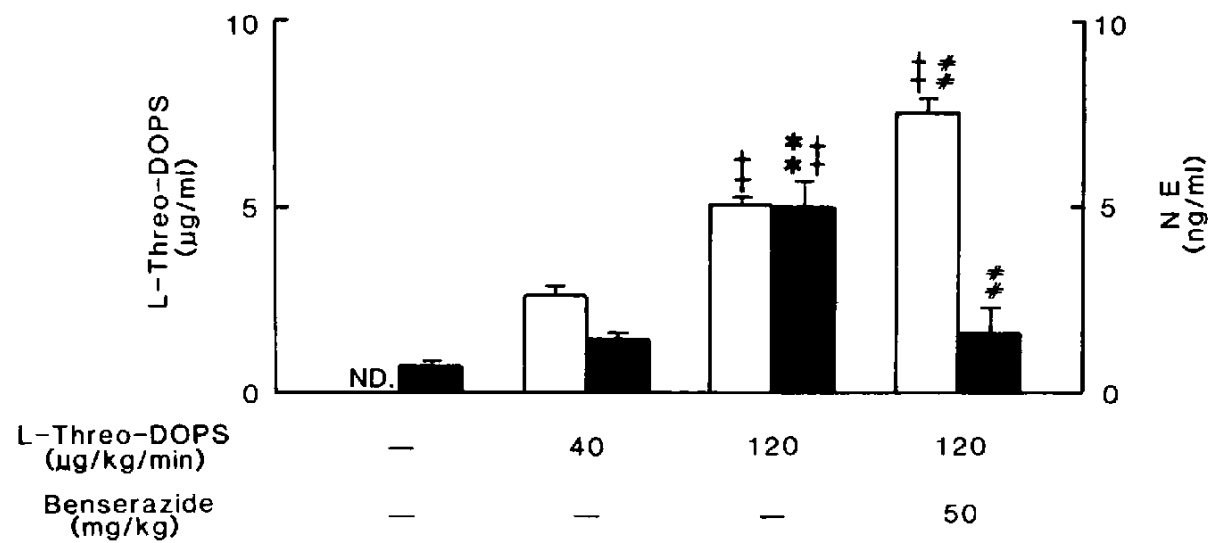

Fig. 5. L-Threo-DOPS ( $\square$ ) and NE ( $\square$ ) concentrations in the plasma after intravenous infusion of L-threo-DOPS. Values are means \pm S.E. $(n=6)$. **P<0.01, compared with the value observed in the time control. $++P<0.01$, compared with the value observed in the L-threo-DOPS $(40 \mu \mathrm{g} / \mathrm{kg} / \mathrm{min})$ administration. \#P<0.01, compared with the value observed in the L-threo-DOPS $(120 \mu \mathrm{g} / \mathrm{kg} / \mathrm{min})$ administration. 
was maintained at a constant level by constricting the clamp, the diuretic action of Lthreo-DOPS was completely abolished. Under these conditions, slight decreases in UF and $U_{\mathrm{Na}} V$ were observed, probably due to the drug-induced renal vasoconstriction. Thus, it seems that $L$-threo-DOPS-induced diuresis is closely related to the hypertensive effect of the drug.

Pretreatment with an AADC inhibitor benserazide also abolished the pressor and diuretic actions of $L$-threo-DOPS, thereby suggesting that NE converted from L-threoDOPS is responsible for the above actions. To confirm this possibility, we determined the plasma levels of L-threo-DOPS and NE. Results clearly indicated that plasma NE levels were increased markedly during Lthreo-DOPS infusion, and the increased levels were suppressed near the control level by pretreatment with benserazide. Moreover, a peripheral $\alpha$-adrenergic blockade with phentolamine significantly suppressed the diuretic effect of L-threo-DOPS as well as the drug-induced hypertensive action. All these findings lead us to suggest that the diuresis during the infusion of $L$-threo-DOPS is due to the "pressure diuresis" (13) induced by NE converted from $L$-threo-DOPS and that the activation of peripheral $\alpha$-adrenoceptors is mainly responsible for the hypertensive action.

The pressure diuresis is a well-described physiological phenomenon in adult animals (13-16). Several studies (17-20) have proposed a contribution of some physical factor to such a phenomenon, i.e., the increase in systemic blood pressure is transmitted to the peritubular capillaries, and the resultant elevation of capillary pressure causes a decrease in water and sodium reabsorption at the proximal and distal tubules. On the other hand, humoral factors such as prostaglandins and the reninangiotensin system $(21,22)$ are also reported to be involved in the pressure diuresis. However, the precise mechanisms and tubular sites in which the phenomenon occurs remain to be determined (13).

In our study, when the $\alpha$-adrenoceptor antagonist phentolamine was administered. at a dose which can completely inhibit the hypertensive action of exogenously applied $N E$, the antagonist attenuated markedly but did not abolish the pressor effect of $\mathrm{L}$-threoDOPS. On the other hand, the combination of phentolamine and the $\beta$-adrenoceptor antagonist propranolol inhibited completely the pressor effect of L-threo-DOPS (data not shown). These findings indicate that some factor via $\beta$-adrenoceptor activation partly contributes to the $L$-threo-DOPS-induced hypertension. We observed in some rats that the infusion of L-threo-DOPS produced an increase in plasma renin activity, an event which elevates the level of vasoactive angiotensin II. The renin release mechanisms via $\beta$-adrenoceptor activation is well-established (23). Thus, NE converted from L-threo-DOPS may elevate the blood pressure via the stimulation of the renin-angiotensin system. Alternatively, the stimulatory effect on the heart via $\beta$-adrenoceptor activation may be indirectly related to $L$-threo-DOPS-induced hypertension.

In the present study, the direct action of $L$ threo-DOPS on renal function was also investigated. To examine this, an intrarenal arterial infusion of $\mathrm{L}$-threo-DOPS at a nonhypertensive dose was carried out, in the presence or absence of pretreatment with benserazide. However, the drug infusion was without effect, thereby indicating that Lthreo-DOPS has no direct action on renal function.

In conclusion, an intravenous administration of $L$-threo-DOPS produces a hypertensive effect and a diuretic effect in anesthetized rats. The diuretic effect is mainly due to the "pressure diuresis" via the peripheral $\alpha$-adrenergic activation induced by NE converted by $A A D C$.

\section{References}

1 Inagaki, C. and Tanaka, C.: Churacteristics of enzymic decarboxylation of L-threo-3,4-dihydroxyphenylserine using hog renal L-aromatic amino acid decarboxylase. Biochem. Pharmacol. 27, 1081-1086 (1978)

2 Bartholini, G., Constantinidis, J., Puig, M., Tissot, R. and Pletscher, A.: The stereoisomers of 3.4-dihydroxyphenylserine as precursors of norepinephrine. J. Pharmacol. Exp. Ther. 193, 5,23532 (1975)

3 Narabayashi, H., Kondc, T., Hayashi, A, Suzuki, T. and Nagatsu, T.: L-Threo-3.4-dihydroxyphenylserine treatment for akiresia and freezing 
of parkinsonism. Proc. Japan. Acad. 57, 351-354 (1981)

4 Suzuki, T., Higa, S., Sakoda, S., Hayashi, A., Yamamura, Y.. Takaba, Y. and Nakajima, A.: Orthostatic hypotension in familial amyloid polyneuropathy: Treatment with DL-threo-3.4dihydroxyohenylserine. Neurology 31, 1323 1326 (1981)

5 Katsuyama, M., Kato, T., Karai, N., Nakamura, M. and Katsube, J.: Reversal by L-threo-3.4-dihydroxyphenylserine (L-threo-DOPS), a $\mathrm{L}_{\text {- }}$ norepinephrine precursor of reserpine- or tetrabenazine-induced hypothermia. Arch. Int. Pharmacodyn. Ther 283, 61-70 (1986)

6 Kato, T., Katsuyama, M., Karai, N., Hirose, A., Nakamura, M. and Katsube, J.: Reversal of the reserpine-induced ptosis by L-threo-3,4-dihydroxyphenylserine ( $\mathrm{L}$-threo-DOPS), a (--)norepinephrine precursor, and its potentiation by imipramine or nialamide. Naunyn Schmiedebergs Arch. Pharmacol. 332, 243-246 (1986)

7 Nakamura, M. and Fukushima, H.: The effect of tricyclic antidepressants and neuroleptics on the peripheral and central action of norepinephrine in reserpine-treated mice. Eur. J. Pharmacol. 38, 343-348 (1976)

8 Araki, H., Tanaka, C., Fujiwara, H., Nakamura, M. and Ohmura, I.: Pressor effects of L-threo-3,4dihydroxyphenylserine in rats. J. Pharm. Pharmacol. 33, 772-777 (1981)

9 Katsube, J., Kato, T., Katsuyama, M., Maeda, Y., Nishikawa, S. and Nakamura, M.: Diuretic effect of L-threo-3.4-dihydroxyphenylserine, a noradrenaline precursor, in rats and mice. J. Pharm. Pharmacol. 38, 533-534 (1986)

10 Vurek, G.G. and Pegram, S.E.: Fluorometric method for the determination of nanogram cuantities of inulin. Anal. Biochem. 16, 409-419 (1966)

11 Suzuki, T., Higa, S., Sakoda, S., Ueji, M., Hayashi, A., Takaba, $Y$. and Nakajma, A.: Pharmacokinetic studies of oral L-threo-3,4dihydroxyphenylserine in normal subjects and patients with familial amyloid polyneuropathy. Eur. J. Clin. Pharmacol. 23, 463-468 (1982)

12 Fujiwara, H., Inagaki, C., Ikeda, Y. and Tanaka,
C.: Decarboxylation of stereoisomers of 3.4dihydroxyphenylserine (DOPS) in vitro. Folia Pharmacol. Japon. 72, 891-898 (1976) (Abs. in English)

13 Roman, R.J.: Pressure diuresis mechanism in the control of renal function and arterial pressure. Fed. Proc. 45, 2878-2884 (1986)

14 Guyton, A.C.: Physiological regulation of arterial pressure. Am. J. Cardiol. 8, 401-407 (1961)

15 Cowley. A.W., Jr., Barber, W.J., Lombard, J.H., Osborn, J.L. and Liard, J.F.: Relationship between body fluid volumes and arterial pressure. Fed. Proc. 45, 2864-2870 (1986)

16 Selkurt, E.E., Womack, I. and Dailey, W.N.: Mechanism of natriuresis and diuresis during elevated renal arterial pressure. Am. J. Physiol. 209, 95-99 (1965)

17 Earley, L.E., Martino, J.A. and Friedler, R.M.: Factors affecting sodium reabsorption by the proximal tubules as determined during blockade of distal sodium reabsorption. J. Clin. Invest. 45 , 1668-1684 (1966)

18 Koch, K.M., Aynedjian, H.S. and Bank, N.: Effect of acute hypertension on sodium reabsorption by the proximal tubule. J. Clin. Invest. 47 , 1696-1709 (1968)

19 Bank, N., Aynedjian, H.S., Bansal, V.K. and Goldman, D.M.: Effect of acute hypertemsion on sodium transport by the distal nephron. Am. J. Physiol, 219, 275-280 (1970)

20 Dresser, T.P., Lynch, R.E., Schneider, E.G. and Knox, F.G.: Effect of increases in blood pressure on pressure and reabsorption in the proximal tubule. Am. J. Physiol. 220, 444-447 (1971)

21 Carmones, P.K., Bell, P.D. and Roman, R.J.: Prostaglandins in the sodium excretory response to altered renal arterial pressure in dogs. Am. J. Physicl. 248, F8-F14 (1985)

22 Romero, J.C. and Knox, F.G.: Mechanisms underlying pressure-related natriuresis: The role of the renin-angiotensin and prostaglandin systems, state of the art lecture. Hypertencion 11 , $724-738$ (1988)

23 Keeton, T.K. and Campbell, W.B.: The pharmacologic alteration of renin release. Pharmacol. Rev. 31, 81-227 (1981) 